\title{
Transformation of Melinjo Seed Micropowders into Nanopowders Enhances Extractability of Phenolic Compounds and Tyrosinase Inhibitory Activity
}

(Transformasi Serbuk Mikro Biji Melinjo kepada Serbuk Nano Meningkatkan Pengekstrakan Sebatian Fenolik dan Merencat Aktiviti Tirosinase)

\author{
VienNa SARASWATY, Ni WAYAN Wulan PraWERTi SuPARTA, HeNRY SETIYANTO, \\ HENI RACHMAWATI \& I KETUT ADNYANA*
}

\begin{abstract}
Melinjo (Gnetum gnemon L.) seed powder extract exhibited antioxidant and tyrosinase inhibitory activity, thus showing potential as a dietary supplement or nutraceutical to prevent aging or hyperpigmentation. Previously, we found that particle size plays important role in extraction of bioactive compounds and influences their bioactivity. Thus, it is important to determine a certain particle size for the extraction process. In this study, we investigated the effects of transformation of melinjo seed micropowders into nanopowders by nanomilling using a high-energy ball mill (shaker mill). The effects of melinjo seed powders particle size on its physicochemical characteristics, extraction efficiency and release of phenolic compounds, as well as tyrosinase inhibitory activity were observed. The nanomilling successfully transformed melinjo seed micropowders into nanopowders within 90 min of milling. Particle size analysis showed that melinjo seed nanopowders were produced with a mean particle diameter of $\sim 675 \mathrm{~nm}$ (PI 0.270). Scanning electron microscope (SEM) images of the melinjo seed nanopowders obviously showed a smaller particle size, a smooth surface, amorphous shapes and irregular edges. The melinjo seed nanopowders at mean particle diameter of $\sim 675 \mathrm{~nm}$ exhibited the highest extraction yield and phenolic compounds release. As a consequence, the tyrosinase inhibitory activity of the melinjo seed nanopowders was 4.5 times higher than that of the melinjo seed micropowders. Based on the results obtained in this study, transformation of melinjo seed micropowders into nanopowders is very promising for improving the efficacy of melinjo seed as tyrosinase inhibitor.
\end{abstract}

Keywords: Extractability; melinjo; nanopowders; tyrosinase

\section{ABSTRAK}

Ekstrak serbuk biji Melinjo (Gnetum gnemon L.) mengeluarkan antioksidan dan merencat aktiviti tirosinase sekali gus menunjukkan potensi sebagai makanan tambahan atau nutraseutik untuk mencegah penuaan atau hiperpigmentasi. Sebelum ini, kami mendapati bahawa saiz, zarah memainkan peranan penting dalam pengekstrakan sebatian bioaktif dan mempengaruhi kemujaraban mereka. Oleh itu, adalah penting untuk menentukan saiz zarah tertentu untuk proses pengekstrakan. Dalam kajian ini, kami mengkaji kesan transformasi serbuk mikro biji melinjo kepada serbuk nano oleh pengisaran nano yang menggunakan sebuah kilang pengisar bola tenaga tinggi (kilang penggoncang). Kesan saiz zarah serbuk biji melinjo ke atas ciri-ciri fizikokimia, kecekapan pengekstrakan dan pengeluaran sebatian berfenol, serta merencat aktiviti tirosinase diperhatikan. Pengisaran nano yang berjaya berubah serbuk mikro biji melinjo menjadi serbuk nano dalam 90 min masa pengilangan. Analisis saiz zarah menunjukkan bahawa serbuk nano biji melinjo dihasilkan dengan diameter zarah min 675 mm (PIO.270). Imej-imej mikroskop elektron (SEM) serbuk nano biji melinjo jelas menunjukkan saiz zarah yang lebih kecil, bentuk amorfus, permukaan licin dan tepi tidak teratur. Serbuk nano biji melinjo pada diameter zarah min $~ 675 \mathrm{~nm}$ menunjukkan hasil perahan yang tertinggi dan sebatian fenol lepas. Akibatnya, aktiviti merencat tirosinase serbuk nano biji melinjo adalah sebanyak 4.5 kali lebih tinggi daripada serbuk mikro biji melinjo. Berdasarkan keputusan yang diperoleh dalam kajian ini, transformasi serbuk mikro biji melinjo kepada serbuk nano sangat berpotensi untuk memperbaiki keberkesanan biji melinjo sebagai perencat tirosinase.

Kata kunci: Melinjo; pengekstrakan; serbuk nano; tirosinase

\section{INTRODUCTION}

Tyrosinase is an enzyme that plays an important role in melanin biosynthesis through melanogenesis. A tyrosinase inhibitor directly inhibits tyrosinase catalase activity (D'Mello et al. 2016). Thus, tyrosinase inhibitors are often used as skin lightening agent. Many chemically synthesized tyrosinase inhibitors, such as hydroquinone, kojic acid, azelaic acid, and L- ascorbic acid, are harmful, cytotoxic, and linked to a number of adverse effects (Couteau \& Coiffard 2016). Therefore, there is a great need of finding alternative tyrosinase inhibitors from natural product sources. 
Melinjo seeds are proven to have extensive pharmacology activities including antioxidant, antitumor, anti-obesity, anti-inflammation, antidiabetic, as well as downregulate osteoclast activity at sites with periodontitis (Barua et al. 2015; Ikeda et al. 2018; Saraswaty et al. 2017a; Yoneshiro et al. 2018). The potency of melinjo seeds to prevent skin hyperpigmentation has been demonstrated by Ohguchi et al. (2003) and Yanagihara et al. (2012) with a mechanism under inhibition of tyrosinase enzyme (Ohguchi et al. 2003; Yanagihara et al. 2012). The tyrosinase inhibitory potency of gnetol, a compound isolated from melinjo seed extract, was 30 times stronger than that of kojic acid, with an inhibitory concentration (IC) ${ }_{50}$ value of $1.1 \mathrm{mg} / \mathrm{mL}$ (Ohguchi et al. 2003). Meanwhile, gnetin $C$ and resveratrol are active in inhibiting tyrosinase enzyme with $\mathrm{IC}_{50}$ values of 7.0 and 7.2 $\mu \mathrm{M}$, respectively (Yanagihara et al. 2012). Gnetin C is not only pharmacologically active compound as a tyrosinase inhibitor, it also displays other biological activities, for example antioxidant and antitumor (Barua et al. 2015; Kato et al. 2009; Saraswaty et al. 2017a). Hence, gnetin C (Figure 1(a)) can be used as marker compound from melinjo seed extract.

Extraction of the bioactive compounds from plant material is the most crucial step in the production of biologically active extracts. The process should have a good extraction yield, consume little time, and be cost effective (Altemimi et al. 2017). Furthermore, the bioactive compounds should be produced in optimal quantity because, in general, alternative herbal medicines are consumed in large doses. Studies on the effect of particle size have shown a higher extraction yield from herbal nanoparticles than from microparticles. Furthermore, herbal nanoparticles also demonstrate a better biological activity than microparticles (Borhan et al. 2013a, 2013b; Namdari et al. 2017). Hence, extraction efficiency by reduction of particle size does not only offer a higher yield but also dose reduction. Accordingly, it is essential to determine the optimum particle size for extraction of the source material. When the optimum particle size for extraction is reached, this further improves the benefit of the extract when used in a wide range of applications, such as food products, pharmaceutical products, alternative herbal medicines, dietary supplements and nutraceuticals.

Nanopowders are agglomerates of nanoparticles. They have a high surface area, therefore, are easily absorbed through the skin, lungs and or digestive tract. Study on a proprietary nanopowders coded with TC325 showed that they are highly effective in achieving hemostasis in severe peptic ulcer bleeding (Sung et al. 2010). Further, observation on zinc oxide $(\mathrm{ZnO})$ nanopowders reported that $\mathrm{ZnO}$ nanopowders can imitate the biomolecules' activity, and can be localized in many body systems, thus enhancing the bioavailability and bioactivity of $\mathrm{ZnO}$ as a cytotoxic agent (Rasmussen et al. 2010). Therefore, it is very intriguing to transform the microparticles into nanoparticles for enhancement of its therapeutic value.

Nanoparticles can be obtained through mechanical pulverization. Ball milling and jet milling are widely used for assisting the preparation of nanoparticles (Borhan et al. 2013a, 2013b; Loh et al. 2014). The most important parameters in the ball milling process are milling duration, ratio between sample and beads and mill speed (Gao \& Forssberg 1993; Kuziora et al. 2014). These parameters have a direct influence on the physicochemical characteristics of the milled material. To the best of our knowledge, there are no studies on the effect of particle size on the extraction yield of melinjo seed powder. In this study, nanomilling on melinjo seed powders assisted by a high-energy ball mill (shaker mill) was carried out to transform microparticles of melinjo seed powder into nanoparticles. The effect of milling duration on its physicochemical characteristics and tyrosinase inhibitory activity were evaluated.

\section{MATERIALS AND METHODS}

\section{MATERIALS}

Young or green melinjo seeds were bought from Sumedang, West Java, Indonesia in December 2017 to January 2018. Melinjo seed was identified by the taxonomist of Herbarium Bandungense, School of Life Science and Technology, Bandung Institute of Technology. A voucher specimen of the plant has been deposited (Accession No. 402/I1.CO2.2/PL.2019) in the herbarium for further reference. Ethanol as organic solvent was obtained from Bratachem, Bandung, Indonesia. Potassium dihidrogen phosphate, dipotassium hydrogen phosphate, folin ciocalteau, and potassium carbonate were purchased from eMerck (Darmstaadt, Germany) at p.a grade. L-tyrosine and tyrosinase enzyme were purchased from Sigma Aldrich

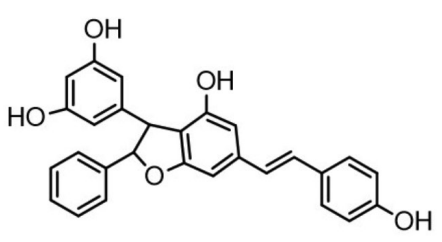

(a)

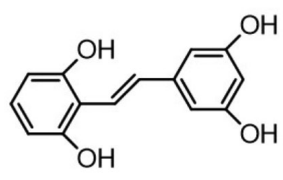

(b)

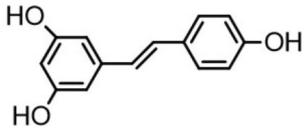

(c)

FIGURE 1. Structure of some phenolic compounds from melinjo seed (gnetin C (a), gnetol (b) and resveratrol (c)) 
(St. Louis, MO, USA). Gnetin C was purchased from Hosoda International (Japan).

\section{METHODS}

Sample Preparation The melinjo seeds were washed with running tap water and rinsed with distilled water to remove any contaminants. Then, the cleaned seeds were peeled to remove the epicarp and mesocarp of the seeds. The endosperms were collected and then stored in $50^{\circ} \mathrm{C}$ controlled oven and left to dry for 3 days. The dried endosperms were grounded using a dry grinder $(10.000$ $\mathrm{rpm}, 2 \mathrm{~min})$. The grounded powders were then stored at room temperature prior to nanomilling.

Nanomilling of Melinjo Seed Powder Nanomilling was conducted in a high energy ball mill (shaker mill) (Ultimate Gravity, Research Centre for Physics, Indonesian Institute of Sciences (LIPI), Tangerang-Banten, Indonesia). The dried and powdered melinjo seeds (5 g) and 10 stainless beads of $50 \mathrm{~g}$ ( $0.5 \mathrm{~cm}$ diameter) were put in the milling chamber. Milling durations of 30,60,90 and 120 min were applied. The nanomilling was stopped for 10 min every 15 min to avoid excessive heat. The powders obtained by nanomilling were then used for extraction and further analysis.

Preparation of Melinjo Seed Crude Extract Melinjo seed powder samples of about $1.5 \mathrm{~g}$ each, taken before and after nanomilling, were macerated in $15 \mathrm{~mL}$ of ethanol $75 \% \mathrm{v} / \mathrm{v}$ for $24 \mathrm{~h}$ at ambient temperature. About $10 \mathrm{~mL}$ of filtrate was concentrated with an evaporator under vacuum (Heidolph Instrument GmbH \& Co. KG, Schwabach, Germany).

For the preparation of aqueous extract, $15 \mathrm{~g}$ of melinjo seed powders in $150 \mathrm{~mL}$ of aquadest was boiled for 15 min and the extract was cooled into room temperature. Consequently, the extract was then filtered and evaporated under vacuum. Both, aqueous and ethanol extract were then assayed for tyrosinase inhibitory activity.

The extraction yield was then determined using the following formula:

$$
\text { Yield } \%=\frac{\text { Weight of concentrated extract }(g)}{\text { Weight of dried sample }(g)} \times 100 \%
$$

The concentrated extracts were kept in a refrigerator prior to analysis.

Particle Size Analysis (PSA) and Morphology The particle size of the melinjo seed powders before and after nanomilling was measured by dynamic light scattering method using a particle size analyzer (Delsa ${ }^{\mathrm{TM}}$ Nano, Beckman Coulter, Brea, CA, USA). Prior to the particle size analysis, a suspension of each sample was taken out and sonicated for $30 \mathrm{~min}$. The suspensions were introduced into a disposable cuvette to be measured. The average particle size and polydispersity index were recorded. Scanning electron imaging was carried out by placing the dry samples onto double sided conducting adhesive carbon tapes and coating them with a gold layer. Micrographs were taken using a scanning electron microscope (JSM IT300, JEOL, Japan) at $20 \mathrm{kV}, 1000 \times$ magnification.

Total Phenolic Content The total phenolic content was determined according to Folin Ciocalteu's method as described in Saraswaty et al. (2017b) using a Hitachi U2800 spectrophotometer (Hitachi, Japan). Gallic acid was used as the standard. The concentration of total phenolic content in the test samples was calculated from the calibration plot and expressed as $\mu \mathrm{g}$ gallic acid equivalent (GAE) per mg of sample (concentrated extract) (Saraswaty et al. 2017b).

\section{HIGH PERFORMANCE LIQUID CHROMATOGRAPHY (HPLC) ANALYSIS}

The extracts and gnetin $\mathrm{C}$ were dissolved in an aquabidest to a concentration of $2 \mathrm{mg} / \mathrm{mL}$ and then filtered through $0.22 \mu \mathrm{m}$ filter paper before being subjected to a HPLC instrument. HPLC analysis was performed on an Agilent 1260 with diode array detector using the ODS column. Solvent A (water) and solvent B (acetonitrile) at a ratio of $1: 1$ were selected as the mobile phase. The injection volume was $20 \mu \mathrm{L}$, the flow rate was $0.8 \mathrm{~mL} / \mathrm{min}$ and the column temperature was maintained at $25^{\circ} \mathrm{C}$. The peak signals were monitored at $280 \mathrm{~nm}$ using a diode array detector. The peaks were characterized by comparing the retention time with the standard. The retention time for the gnetin $\mathrm{C}$ was approximately $3.7 \mathrm{~min}$.

\section{TYROSINASE INHIBITORY ACTIVITY}

Tyrosinase inhibitory activity was carried out in accordance with Teixera et al. (2012) with slight modifications. $25 \mu \mathrm{L}$ of sample was reacted with $80 \mu \mathrm{L}$ phosphate buffer, 125 $\mu \mathrm{L}$ L-tyrosine and $20 \mu \mathrm{L}$ tyrosinase enzymes, and then incubated for $30 \mathrm{~min}$ at room temperature (Teixeira et al. 2012). The absorbance was then recorded using a Multiscan (Nanoquant, Infinite M2000 Pro, TECAN) at $475 \mathrm{~nm}$. The inhibition percentage of tyrosinase enzyme was calculated with the following formula,

$$
\text { Inhibition } \%=\frac{C-S}{S} \times 100 \%
$$

\section{STATISTICAL ANALYSIS}

The Statistical Package for Social Science (SPSS) Version 19 (IBM Australia Limited, St Leonards, NSW, Australia) was used for the data analysis. All experiments were conducted in triplicate and the data are presented as mean \pm standard deviation (SD).

\section{RESULTS AND DISCUSSION}

\section{THE POTENCY OF MELINJO SEED AS TYROSINASE INHIBITOR}

The tyrosinase inhibitory activity of melinjo seeds before nanomilling in aqueous and ethanol based extract was 
shown in Figure 2. As depicted the melinjo seed aqueous based extract at 200 and 1000 ppm showed no tyrosinase inhibitory activity. Whereas, the ethanol based extract at $200 \mathrm{ppm}$ showed $7.5 \%$ of inhibition. The tyrosinase inhibitory activity observed in the ethanol based extract is probably due to the presence of resveratrol and gnetin $\mathrm{C}$ since both of these compounds are more soluble in ethanol (Robinson et al. 2015; Saraswaty et al. 2017a). Therefore, we selected ethanol based extract for further analysis.

\section{CHARACTERIZATION OF MELINJO SEED NANOPOWDERS}

Melinjo seed nanopowders were prepared by nanomilling without additives using a shaker mill. Nanomilling is a processing technique to reduce particle size below $1000 \mathrm{~nm}$ (Li et al. 2016; Peltonen \& Hirvonen 2010). A shaker mill is a high energy ball mill that can produce nanoparticles in a relatively short time (Wank \& Wielage 2003). The production of nanoparticles occurs as a result of the impact of the collisions between the beads and the wall chamber. Accordingly, a longer milling duration will result in smaller particle sizes (Borhan et al. 2013b). In a shaker mill or ball milling, there is no automated control of the particle size produced. Therefore, in order to produce a specific particle size, it is necessary to determine the milling duration. As shown in Table 1 , the mean particle diameters of melinjo seed powders from various milling durations decreased at $0,30,60,90$ and $120 \mathrm{~min}$, respectively. The polydispersity index (PI) represents the particle size distribution or homogeneity. When the PI value is $<0.3$, it means that the sample has a narrow distribution. Conversely, higher PI values indicate a broader distribution (Yen et al. 2010). As also shown in Table 1, only the nanomilling for 90 min showed PI value below 0.3 , indicating the best homogeneity. Conversely, the longer duration of nanomilling (120 min) showed higher PI value, indicating that the nanopowders started to agglomerate. This study is in agreement with report of Hartley et al. (1985) which confirmed that particles at submicron size dominantly agglomerate as the results of the Van der Waals force.

To study probable changes of morphology for melinjo seed powders after nanomilling as well as to confirm the PSA results, samples were subjected to SEM investigation. The SEM images (Figure 3(a)-3(e)) obviously depicted the fragmentation of particles from micro into nano size. Microparticles exist in the melinjo seed powders milled for 0, 30, and 60 min (Figure 3(a)-3(c)), whereas the nanoparticles were produced at 90 and $120 \mathrm{~min}$ nanomilling duration (Figure 3(d)-3(e)). As can also be seen in Figure 3(e), the melinjo seed powders milled for 120 min showed a higher degree of agglomeration than that of 90 min which confirmed the cause of the PI elevation. Thus, a nanomilling duration of $90 \mathrm{~min}$ is the optimal condition for producing melinjo seed nanopowders.

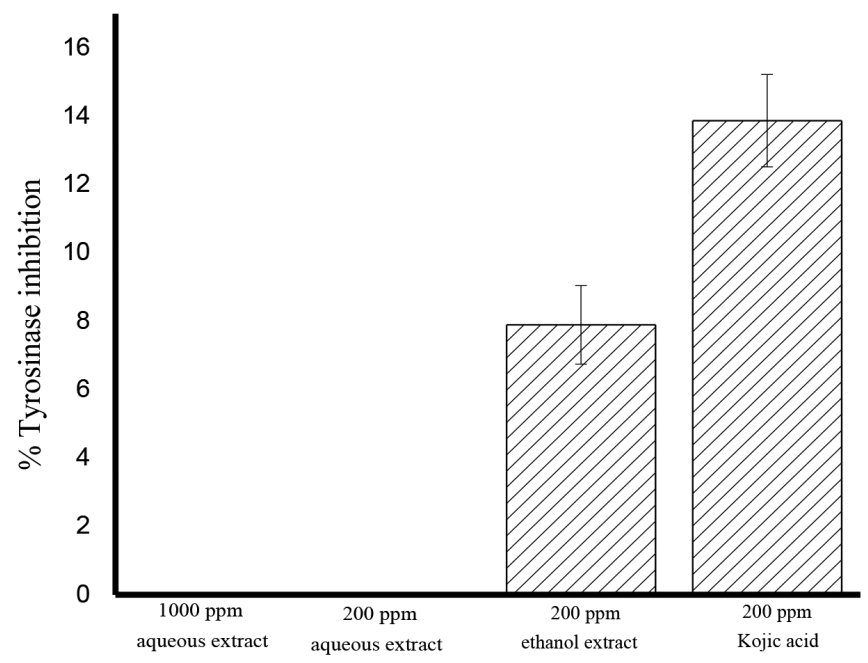

FIGURE 2. Tyrosinase inhibitory activity of melinjo seed aqueos and ethanol based extract. Data presented as mean \pm SD $(n=3)$

TABLE 1. Particle size analysis and polydispersity index of melinjo seed powder before and after nanomilling

\begin{tabular}{ccc}
\hline Nanomilling duration $(\mathrm{min})$ & Mean particle diameter $(\mathrm{nm})$ & Polydispersity index $(\mathrm{PI})$ \\
\hline 0 & 1472.8 & 0.43 \\
30 & 1270.6 & 0.43 \\
60 & 1082.3 & 0.34 \\
90 & 675.6 & 0.27 \\
120 & 650.6 & 0.43 \\
\hline
\end{tabular}




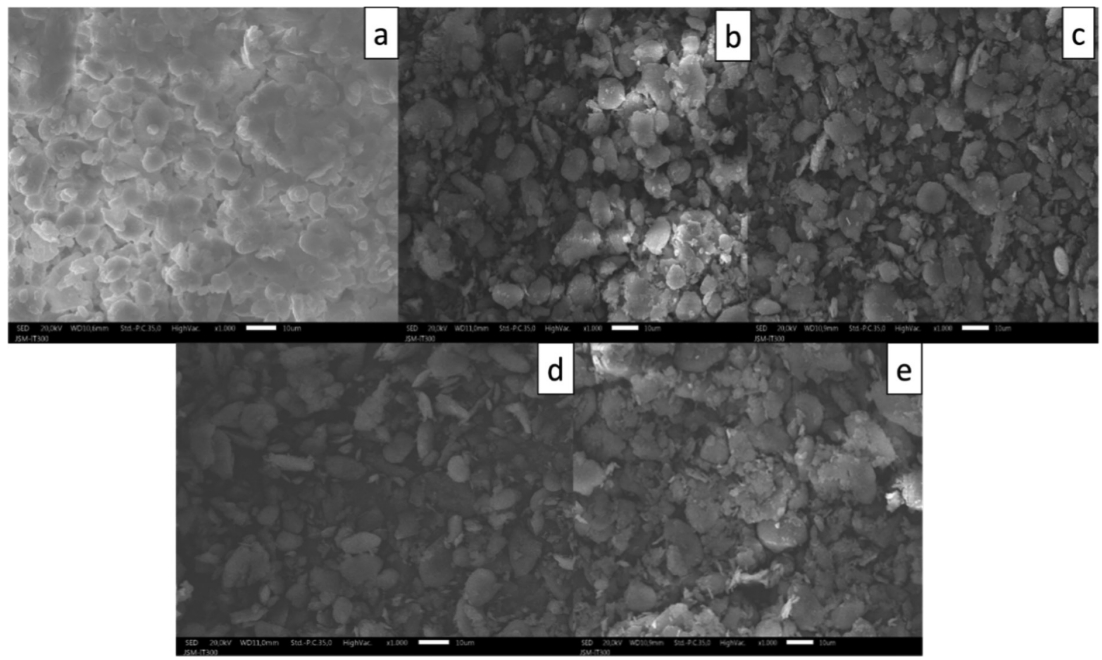

FIGURE 3. SEM micrographs of melinjo seed powder from various milling durations: a) $0 \mathrm{~min}$; b) $30 \mathrm{~min}$, c) $60 \mathrm{~min}$, d) $90 \mathrm{~min}$ and e) $120 \mathrm{~min}$

\section{ENHANCEMENT OF EXTRACTION YIELD AND RELEASE OF PHENOLIC COMPOUNDS}

Figure 4(a) shows the enhancement of the extraction yield after nanomilling of melinjo seed powders. The extraction yield was examined under the following conditions: Sample to volume extraction ratio 1:10 and maceration for 24 h. As can be seen in Figure 4(a), the highest extraction yield was obtained from the melinjo seed powder milled for 90 min with an average particle size of $\sim 675 \mathrm{~nm}$. Although melinjo seed powders milled for 120 min showed a smaller particle size, the extraction yield was lower than the melinjo seed powders which were milled for $90 \mathrm{~min}$. This is probably due to the formation of aggregates getting stronger and reduces the contact ratio between solvent and cell wall material (Brinkmann et al. 2016; Deng et al. 2016; Saleh et al. 2015). Hence, the interaction between solvent and particles becomes more limited, decreasing the efficiency of compound extraction. In conclusion, it is not necessary to conduct nanomilling longer than $90 \mathrm{~min}$ to produce smaller particles since the maximum extraction yield is already achieved after $90 \mathrm{~min}$.

Melinjo seeds are known to contain phenolic compounds called melinjo resveratrol, including resveratrol, gnetol and gnetin C (Figure 1). These compounds exhibit potency as tyrosinase inhibitor (Ohguchi et al. 2003; Yanagihara et al. 2012). Hence, it is essential to calculate the total phenolic content to represent the release efficiency of bioactive compounds from the crude extract. As shown in Figure 4(b), the nanomilling resulted in an enhancement of the release of the total phenolic compound from the melinjo seed powders. The release of phenolic compounds from melinjo seed powders had a similar trend as the extraction yield. The highest of total phenolic content in melinjo seed extract was obtained from melinjo seed powders milled for 90 min, indicating that a mean particle diameter of $\sim 675$ $\mathrm{nm}$ is optimal for releasing phenolic compounds from melinjo seeds. These results have important implications for optimizing the effects of melinjo seeds as a tyrosinase inhibitor.

To confirm the presence of gnetin $\mathrm{C}$ and elevation of phenolic compounds release from melinjo seed powder, we conducted a HPLC analysis on the melinjo seed powder extract. The HPLC chromatograms are shown in Figure 5. As can be seen in Figure 5, many polar compounds appeared at the first 2 min and gnetin $\mathrm{C}$ is present at 3.7 min retention time. A comparison between chromatograms
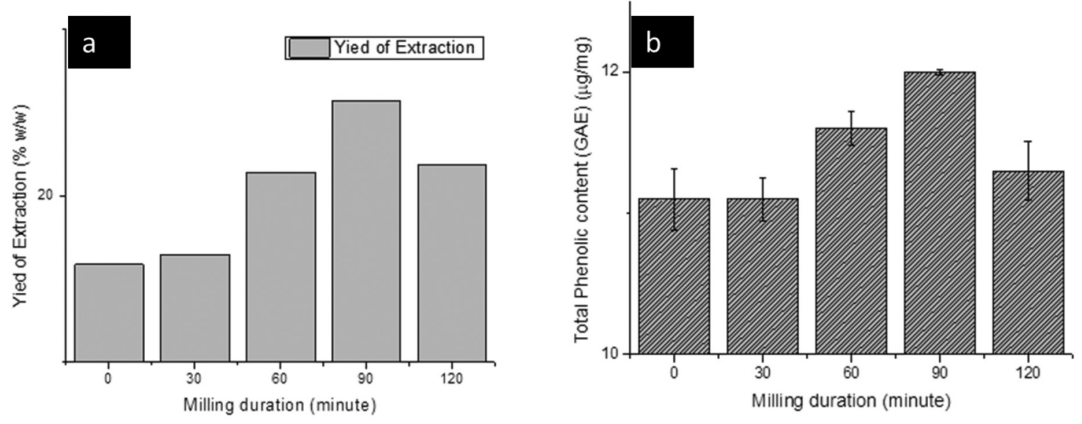

FIGURE 4. Extraction yield (a) and total phenolic content (b) of melinjo seed powders from various nanomilling durations 
showed that the peak of gnetin $\mathrm{C}$ extracted from the melinjo seed micropowders before nanomilling ( $0 \mathrm{~min})$ was higher than the peak of gnetin $\mathrm{C}$ extracted from melinjo seed nanopowders (90 and 120 min, respectively). While conversely, there was a peak in melinjo seed extract produced at a retention time of $1.7 \mathrm{~min}$. Furthermore, the area percentage of the peak at a retention time of $1.7 \mathrm{~min}$ increased from 50.57 to $83.62 \%$. Borhan et al. (2013b) stated that the interactions between the grinding ball and the grinding jar allows the formation of hydronium ions. Therefore, it is possible to break C-O bonds of gnetin $\mathrm{C}$ and form gnetin $\mathrm{C}$ derivative during the nanomilling of melinjo seed powders.

\section{ENHANCEMENT OF TYROSINASE INHIBITORY ACTIVITY}

Finally, the impact of transformation of melinjo seed micropowders into nanopowders on its tyrosinase inhibitory activity was evaluated. This analysis is important to prove the enhancement of the beneficial value of melinjo seed nanopowders to prevent skin problem such as hyperpigmentation. In this experiment, the melinjo seed crude extracts, obtained from various milling durations, were tested at $200 \mathrm{ppm}$ (Figure 6). The tyrosinase inhibitory activity of melinjo seed extracts from the melinjo seed nanopowders was appreciably higher than that of melinjo seed extract from the micropowders. The melinjo seed extract obtained from melinjo seed nanopowders that were milled for 90 min exhibited the highest tyrosinase inhibitory activity (35.46\%), while the unmilled one exhibited the poorest activity (7.93\%). This result showed that nanomilling elevated the tyrosinase inhibitory activity of the melinjo seed extract up to 4.5 folds. Studies on the effect of particle size demonstrated that drug particles at nano-size improve the release of bioactive compounds thus enhancing their biological activity (Borhan et al. 2013; Huang et al. 2016; Li et al. 2016; Onodera et al. 2015; Tian et al. 2014). Our result confirmed that the production of melinjo seed nanopowders improves the release of phenolic compounds, elevating the tyrosinase inhibitory activity.

\section{CONCLUSION}

In summary, melinjo seed nanopowders were successfully produced by nanomilling using a high energy ball mill
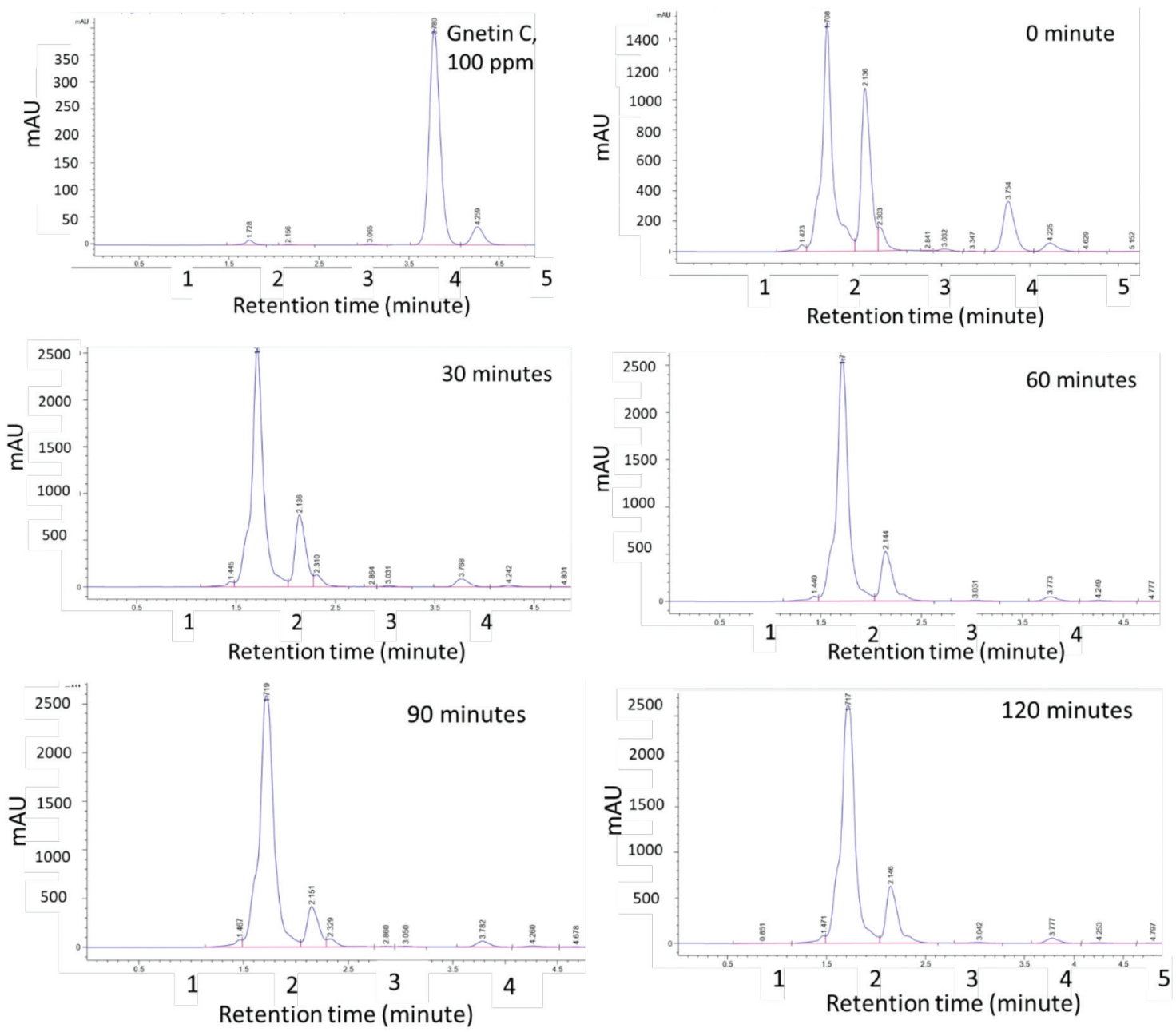

FIGURE 5. HPLC chromatograms of gnetin C and melinjo seed ethanol extract from various nanomilling durations 


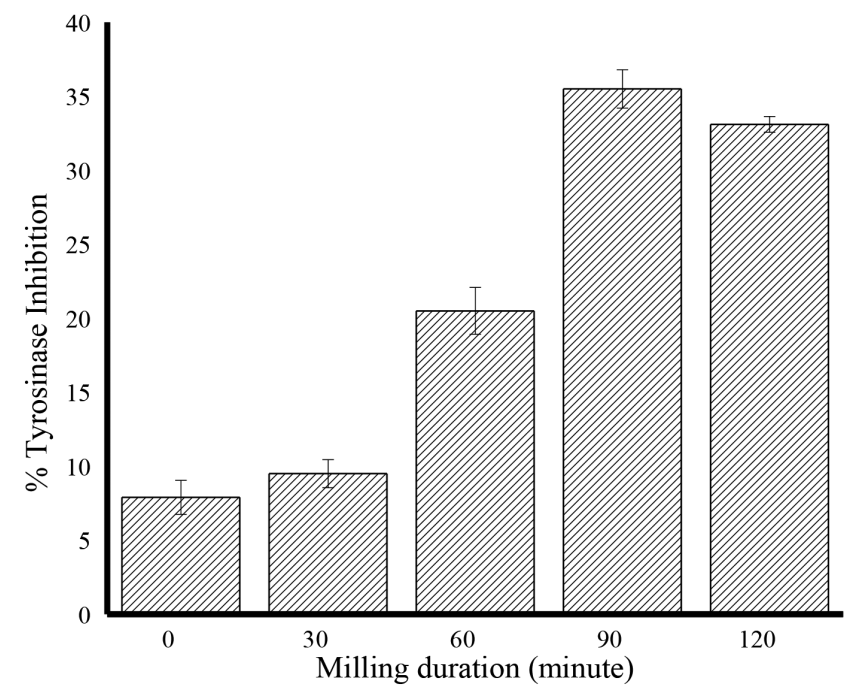

FIGURE 6. Inhibition of tyrosinase enzyme of melinjo seed ethanol extract from various nanomilling durations. Data values expressed as mean $\pm \operatorname{SD}(n=3)$

(shaker mill). This study demonstrated that particle size reduction changes of physicochemical properties of melinjo seed powders. The elevation of extraction yield and phenolic compound release are leading to enhancement of tyrosinase inhibitory activity. As a result, we suggest that melinjo seed nanopowders could be used to prevent skin hyperpigmentation via a lower dose. Moreover, the use of melinjo seed nanopowders merits further study for clinical application as a dietary supplement, nutraceutical and/or pharmaceutical products.

\section{ACKNOWLEDGEMENTS}

This research was financially supported by Riset KK-A ITB 2018. The authors thank the Analytical Chemistry Laboratory, Department of Mathematic and Natural Sciences- ITB, Research Unit for Clean Technology, Indonesian Institute of Sciences (LIPI), Bandung, Indonesia and School of Pharmacy-ITB for the use of their research facilities. Authors also thank scholarship SAINTEK Dikti under vs.

\section{REFERENCES}

Altemimi, A., Lakhssassi, N., Baharlouei, A., Watson, D.G. \& Lightfoot, D.A. 2017. Phytochemicals: Extraction, isolation, and identification of bioactive compounds from plant extracts. Plants 6: 42.

Barua, C.C., Haloi, P. \& Barua, I.C. 2015. Gnetum gnemon Linn.: A comprehensive review on its biological, pharmacological and pharmacognostical potentials. International Journal of Pharmacognosy and Phytochemical Research 7(3): 531-539.

Borhan, M.Z., Ahmad, R., Rusop, M. \& Abdullah, S. 2013a. Green extraction: Enhanced extraction yield of asiatic acid from Centella asiatica (L.) nanopowders. Journal of Applied Chemistry 2013: 1-7.

Borhan, M.Z., Ahmad, R., Rusop, M. \& Abdullah, S. 2013b. Optimization of ball milling parameters to produce Centella asiatica herbal nanopowders. Journal of Nanostructure in Chemistry 3: 79.

Brinkmann, A., Chen, M., Couillard, M., Jakubek, Z.J., Leng, T. \& Johnston, L.J. 2016. Correlating cellulose nanocrystal particle size and surface area. Langmuir 32(24): 6105-6114.

Couteau, C. \& Coiffard, L. 2016. Overview of skin whitening agents: Drugs and cosmetic products. Cosmetics 3: 27.

D’Mello, S.A., Finlay, G.J., Baguley, B.C. \& AskarianAmiri, M.E. 2016. Signaling pathways in melanogenesis. International Journal of Molecular Sciences 17(7): 1144.

Deng, X., Huang, Z., Wang, W. \& Davé, R.N. 2016. Investigation of nanoparticle agglomerates properties using monte carlo simulations. Advanced Powder Technology 27(5): 1971-1979.

Gao, M.W. \& Forssberg, E. 1993. A study on the effect of parameters in stirred ball milling. International Journal of Mineral Processing 37(1-2): 45-59.

Hartley, P.A., Parfitt, G.D. \& Pollack, B. 1985. The role of the Van Der Waals force in the agglomeration of powders containing submicron particles. Powder Technology 42(1): 35-46.

Huang, X., Huang, X., Gong, Y., Xiao, H., McClements, D.J. \& Hu, K. 2016. Enhancement of curcumin water dispersibility and antioxidant activity using core-shell protein-polysaccharide nanoparticles. Food Research International 87: 1-9.

Ikeda, E., Ikeda, Y., Wang, Y., Fine, N., Sheikh, Z., Viniegra, A., Barzilay, O., Ganss, B., Tenenbaum, H.C. \& Glogauer, M. 2018. Resveratrol derivative-rich melinjo seed extract induces healing in a murine model of established periodontitis. Journal of Periodontology 89(5): 586-595.

Kato, E., Tokunaga, Y. \& Sakan, F. 2009. Stilbenoids isolated from the seeds of melinjo (Gnetum gnemon L.) and their biological activity. Journal of Agricultural and Food Chemistry 57(6): 2544-2549.

Kuziora, P., Wyszyńska, M., Polanski, M. \& Bystrzycki, J. 2014. Why the ball to powder ratio (BPR) is insufficient for describing the mechanical ball milling process. International Journal of Hydrogen Energy 39(18): 9883-9887.

Li, M., Azad, M., Davé, R. \& Bilgili, E. 2016. Nanomilling of drugs for bioavailability enhancement: A holistic formulationprocess perspective. Pharmaceutics 8(2): 17. 
Loh, Z.H., Samanta, A.K. \& Heng, P.W.A. 2014. Overview of milling techniques for improving the solubility of poorly water-soluble drugs. Asian Journal of Pharmaceutical Sciences 10(4): 255-274.

Namdari, M., Eatemadi, A., Soleimaninejad, M. \& Hammed, A.T. 2017. A brief review on the application of nanoparticle enclosed herbal medicine for the treatment of infective endocarditis. Biomedicine \& Pharmacotherapy 87: 321-331.

Ohguchi, K., Tanaka, T., Iliya, I., Ito, T., Iinuma, M., Matsumoto, K., Akao, Y. \& Nozawa, Y. 2003. Gnetol as a potent tyrosinase inhibitor from genus gnetum. Bioscience, Biotechnology, and Biochemistry 67(3): 663-665.

Onodera, T., Kuriyama, I., Andoh, T., Ichikawa, H., Sakamoto, Y., Lee-Hiraiwa, E. \& Mizushina, Y. 2015. Influence of particle size on the in vitro and in vivo anti-inflammatory and anti-allergic activities of a curcumin lipid nanoemulsion. International Journal of Molecular Medicine 35(6): 17201728.

Peltonen, L. \& Hirvonen, J. 2010. Pharmaceutical nanocrystals by nanomilling: Critical process parameters, particle fracturing and stabilization methods. Journal of Pharmacy and Pharmacology 62(11): 1569-1579.

Rasmussen, J.W., Matinez, E., Louka, P. \& Wingett, D.G. 2010. Zinc oxide nanoparticles for selective destruction of tumor cells and potential for drug delivery applications. Journal of Expert Opinion on Drug Delivery 7(9): 1063-1077.

Robinson, K., Mock, C. \& Liang, D. 2015. Pre-formulation studies of resveratrol. Drug Development and Industrial Pharmacy 41(9): 1464-1469.

Saleh, I.A., Kamal, S.A., Shams, K.A., Abdel-Azim, N.S., Aboutabl, E.A. \& Hammouda, F.Z. 2015. Effect of particle size on total extraction yield and silymarin content of Silybum marianum L. seeds. Research Journal of Pharmaceutical, Biological and Chemical Sciences 6(2): 803-809.

Saraswaty, V., Adnyana, I.K., Pudjiraharti, S., Mozef, T., Insanu, M., Kurniati, N.F. \& Rachmawati, H. 2017a. Fractionation using adsorptive macroporous resin HPD-600 enhances antioxidant activity of Gnetum gnemon L. seed hard shell extract. Journal of Food Science and Technology 54(10): 3349-3357.

Saraswaty, V., Risdian, C., Primadona, I., Andriyani, R., Andayani, D.G.S. \& Mozef, T. 2017b. Pineapple peel wastes as a potential source of antioxidant compounds. In IOP Conference Series: Earth and Environmental Science. Volume 60. https:// iopscience.iop.org/articles/10.1088/1755-1315/60/1/012013/ pdf. Accessed on 27 April 2018.

Sung, J.J., Luo, D., Wu, J.C., Ching, J., Chan, F.K., Lau, J.Y., Mack, S., Ducharme, R., Surti, V.C., Okolo, P.I., Canto, M.I., Kallo, A.N. \& Giday, S.A. 2010. S1575: Nanopowders are highly effective in achieving hemostasis in severe peptic ulcer bleeding: An interim report of a prospective human trial. Gastrointestinal Endoscopy 71(5): AB198.

Teixeira, R.S., Rocha, P.R., Polonini, H.C., Brandão, M.A.F., Chaves, M.G.A.M. \& Raposo, N.R.B. 2012. Mushroom tyrosinase inhibitory activity and major fatty acid constituents of amazonian native flora oils. Brazilian Journal of Pharmaceutical Sciences 48(3): 399-404.
Tian, Y., Wang, X., Xi, R., Pan, W., Jiang, S., Li, Z., Zhao, Y., Gao, G. \& Liu, D. 2014. Enhanced antitumor activity of realgar mediated by milling it to nanosize. International Journal of Nanomedicine 9(1): 745-757.

Wank, A. \& Wielage, B. 2003. High energy ball milling - A promising route for production of tailored thermal spray consumables. Conference on Modern Wear and Corrosion Resistant Coatings Obtained by Thermal Spraying, Warsaw, P. November $20^{\text {th }}-21^{\text {st }}$, 2003. https://www.gtv-mbh.com/old/ gtv-mbh-englisch/www.gtv-mbh.de/cms/upload/ publikat/ Wank/ english/2003_05_eng.pdf.

Yanagihara, M., Yoshimatsu, M., Inoue, A., Kanno, T., Tatefuji, T. \& Hashimoto, K. 2012. Inhibitory effect of gnetin C, a resveratrol dimer from melinjo (Gnetum gnemon), on tyrosinase activity and melanin biosynthesis. Biological \& Pharmaceutical Bulletin 35(6): 993-996.

Yen, F.L., Wu, T.H., Tzeng, C.W., Lin, L.T. \& Lin, C.C. 2010. Curcumin nanoparticles improve the physicochemical properties of curcumin and effectively enhance its antioxidant and antihepatoma activities. Journal of Agricultural and Food Chemistry 58(12): 7376-7382.

Yoneshiro, T., Kaede, R., Nagaya, K., Saito, M., Aoyama, J., Elfeky, M., Okamatsu-Ogura, Y., Kimura, K. \& Terao, A. 2018. Melinjo (Gnetum gnemon L.) seed extract induces uncoupling protein 1 expression in brown fat and protects mice against diet-induced obesity, inflammation, and insulin resistance. Nutrition Research 58: 17-25.

Vienna Saraswaty, Ni Wayan Wulan Prawerti Suparta, Heni Rachmawati \& I Ketut Adnyana*

School of Pharmacy

Institut Teknologi Bandung

Jalan Ganesha no. 10, Bandung

Indonesia

Vienna Saraswaty

Research Unit for Clean Technology

Indonesian Institute of Sciences

Jalan Cisitu Sangkuriang Gd. 50, Bandung

Indonesia

Henry Setiyanto

Analytical Chemistry Research Group

Institut Teknologi Bandung

Jalan Ganesha no. 10, Bandung

Indonesia

*Corresponding author; email: ketut@fa.itb.ac.id

Received: 20 September 2018

Accepted: 20 March 2019 